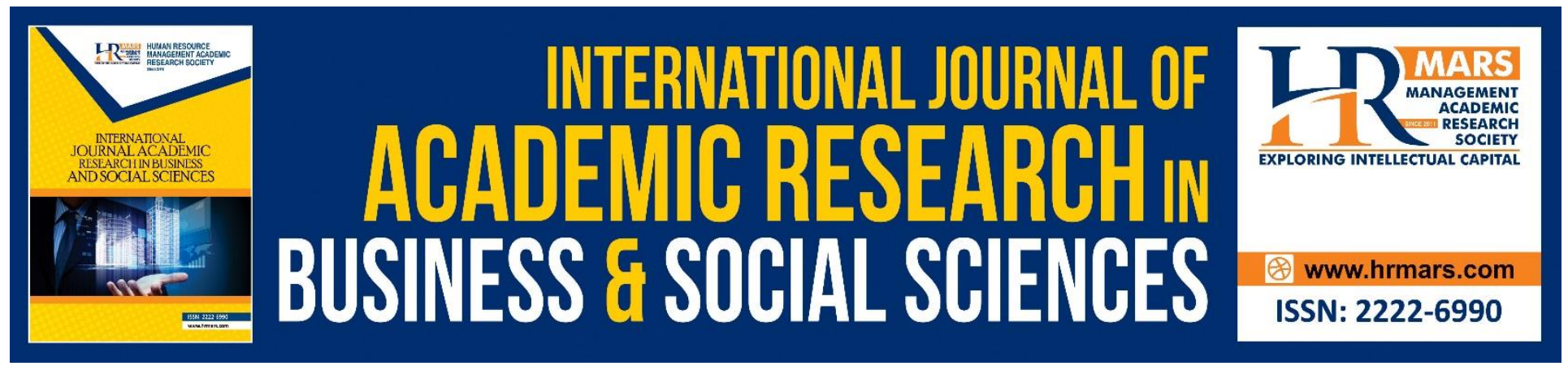

\title{
Sustainability Reporting and Board Diversity in Malaysia
}

\author{
Aishah Binti Sheikh Abu Bakar, Nazli Anum Binti Mohd. Ghazali, \\ Maslina Binti Ahmad
}

To Link this Article: http://dx.doi.org/10.6007/IJARBSS/v9-i3/5663

DOI: $\quad 10.6007 /$ IJARBSS/v9-i3/5663

Received: 14 Jan 2019, Revised: 21 Feb 2019, Accepted: 08 March 2019

Published Online: 16 March 2019

In-Text Citation: (Bakar, Ghazali, \& Ahmad, 2019)

To Cite this Article: Bakar, A. B. S. A., Ghazali, N. A. B. M., \& Ahmad, M. B. (2019). Sustainability Reporting and Board Diversity in Malaysia. International Journal of Academic Research in Business and Social Sciences, 9(2), 1044-1067.

\section{Copyright: (C) 2019 The Author(s)}

Published by Human Resource Management Academic Research Society (www.hrmars.com)

This article is published under the Creative Commons Attribution (CC BY 4.0) license. Anyone may reproduce, distribute, translate and create derivative works of this article (for both commercial and non-commercial purposes), subject to full attribution to the original publication and authors. The full terms of this license may be seen

at: http://creativecommons.org/licences/by/4.0/legalcode

Vol. 9, No. 3, 2019, Pg. 1044 - 1067

http://hrmars.com/index.php/pages/detail/IJARBSS

JOURNAL HOMEPAGE

Full Terms \& Conditions of access and use can be found at http://hrmars.com/index.php/pages/detail/publication-ethics 


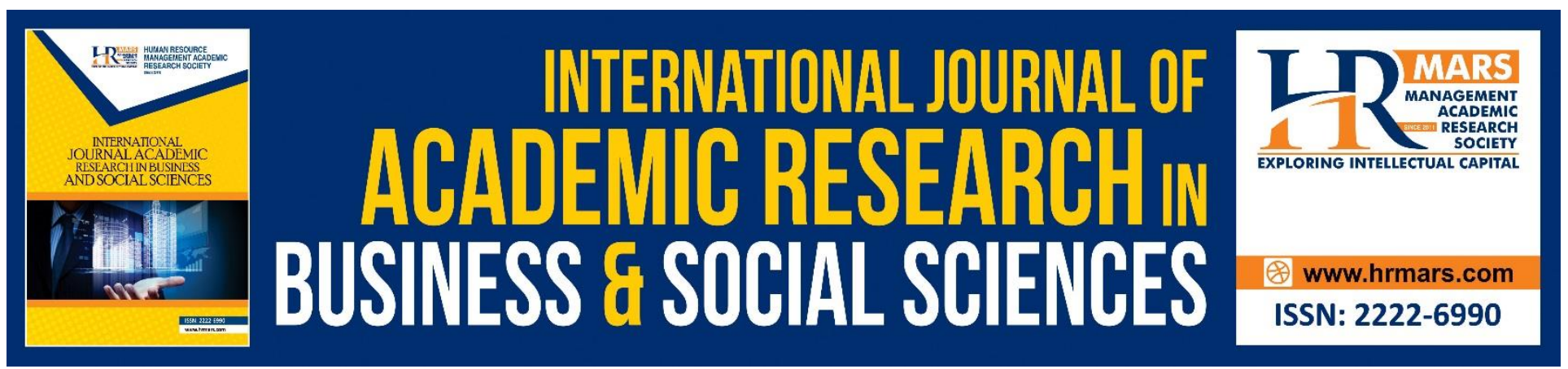

\title{
Sustainability Reporting and Board Diversity in Malaysia
}

\author{
Aishah Binti Sheikh Abu Bakar \\ Department of Commerce, Politeknik Ungku Omar, Malaysia
}

Nazli Anum Binti Mohd. Ghazali

Department of Accounting, KENMS, International Islamic University of Malaysia

Maslina Binti Ahmad

Department of Accounting, KENMS, International Islamic University of Malaysia

\begin{abstract}
This study examines the extent and quality of Sustainability Reporting among Malaysian listed companies after the amendment of listing requirement in October 2015. In addition the study also examines the impact of corporate governance element, which is board diversity on Sustainability Reporting. This study uses content analysis method and independent t-test to accomplish the objectives. The extent and quality of SR among Malaysian listed companies are still low. In addition, it also found that companies that have female-gender board member have significant impact on their SR but not for age and ethnic diversity. Female directors have different way of perceptions, thinking and ideas that could impact companies' sustainability initiatives and reporting. The study contributes to the literature of corporate governance-sustainability by focusing specifically the impact of board diversity on SR.
\end{abstract}

Keywords: Sustainability Reporting, Corporate governance, Board Diversity, Gender, Age and Ethnic.

\section{Introduction}

Due to financial crises such as accounting and compensation scandals, market players such as investors, shareholders and creditors are now more concern on social and environmental implications caused by companies' operations (Amran, Ooi, Mydin, \& Devi, 2015). This concern increases the importance of corporate sustainability practices and therefore should be included in each company main agenda. To enhance corporate accountability and transparency, companies are encouraged to disclose sustainability information in their annual reports. Thus, it increases the need to disclose sustainability information in their annual corporate report. 
Previously, disclosing sustainability information in corporate annual report is on voluntarily basis. However, according to KPMG (2015) reports in its latest survey, the number of companies that disclose their CR reporting is increasing. Further stated, one of the main driving factors is government regulation.

As for Malaysian listed companies, it is mandatory to disclose the corporate social responsibility (CSR) activities in the companies' annual report starting from year 2007 (Bursa Malaysia Listing Requirement in 2006). However, there were no comprehensive guidelines regarding the type of sustainability information that should be disclosed and how the information should be disclosed. As a result, the extent and quality of Sustainability Reporting ${ }^{1}$ (SR) in Malaysia has not been extensively reported and the quality of information disclosed is low (Abd-Mutalib, Jamil, \& WanHussin, 2014; Ahmad, Sulaiman, \& Siswantoro, 2003; Ahmed Haji, 2013; Mohd Ghazali, 2007). It was found that, most companies were reporting what they wanted to disclose and they were inclined to disclose on community and social aspect which were mostly qualitative rather than quantitative information.

In October 2015, Bursa Malaysia issued a Sustainability Reporting Guide (SRG) to listed companies as a guide to prepare the SR in their annual reports. Concurrently, Bursa Malaysia made amendment in its Listing Requirements pertaining to sustainability (paragraph 29, part A of Appendix 9C, Main Market LR and practice note 9, Main Market). The SRG provides more specific guidance on "what" and "how" sustainability information should be disclosed by companies in their SR. With these new requirements on SR, it is expected that companies will provide more comprehensive and extensive reporting, which is one of the objectives of this study.

Furthermore, the boards are accountable in promoting sustainability pertaining to environment, social and governance (ESG) aspects under the principle 1, recommendation 1.4 of Malaysia Code of Corporate Governance 2012 (MCCG, 2012). The board of directors should ensure that the companies have strategies in promoting sustainability pertaining to environment, social and governance (ESG) aspects. Since board of directors plays an important role, in recent MCCG 2017, board diversity is given much attention. It is believed that, in order to enhance good corporate governance and to sustain in the business, companies are required to consider board diversity in term of age, cultural background, gender, skills and experience in their board composition. By having board members from diverse background, it may provide the board with various thinking, perceptions, ideas and suggestions to respond to business challenges, prevent 'groupthink' in the decision-making process and deliver value (MCCG, 2017).

As a growing emerging economy, Malaysia is a good example for a study on business developments and its effects on SR. First, to help companies to report extensively and of high-quality information, Bursa Malaysia launched amended listing requirement pertaining to SR and together with the SRG in October 2015. Second, the Security Commission revised the MCCG in 2012 which emphasized on the board accountability and responsibility to embed sustainability in their business

\footnotetext{
1 The term 'Sustainability Reporting' is used interchangeably with other terms such as Corporate Social Responsibility Reporting (CSRR), CSR disclosure; and Social and Environment Reporting, etc. It is based on the definition of sustainable development as "development that meets the needs of the present without compromising the ability of future generations to meet their own needs" (the Brundtland Report of the World Commission on Environment and Development in 1987).
} 
and make the reporting clearly and transparent. Moreover, the MCCG once again was revised in 2017 which emphasized on the board diversity as one of the criteria in board composition.

There are two objectives of this study. The first objective is to examine the extent and quality of SR of Malaysian listed companies after the implementation of SRG in 2015. The second objective is to determine if board diversity has an impact on SR. The study found that the extent and quality of SR after the issuance of SRG are increasing compared to previous studies, however it still low. In addition, the study also found that companies which have female board member have significant impact on their SR. Female directors have different way of perceptions, thinking and ideas that could impact companies' sustainability initiatives and reporting. The study contributes to the literature on corporate governance-sustainability in a number of ways. Firstly, it focuses on Malaysia context and it is one of the developing countries that experience a tremendous development in its public listed companies' sustainability framework. With the amended listing requirement on SR by Bursa Malaysia, this study contributes in examining the evolution of SR as well as corporate governance in Malaysia environment. Secondly, this study uses a recent data, 2016, the first year of SRG implementation. As a result, this study can serve as a benchmark for comparison among developing countries that experience the same mandatory requirements. Thirdly, the current study compliments previous studies by examining the extent and quality of SR using a check list suggested by Bursa Malaysia (which has not yet been used in other prior studies, so far). Lastly, the study contributes to the literature of corporate governance-sustainability by focusing specifically the impact of board diversity on SR. The board of directors through its board diversity, will help companies to have good SR by playing monitoring role as well as resource provider (Hillman \& Dalziel, 2003).

The following section discusses the background and literature review on SR and board diversity. The third section elaborates the research method and the last section discusses the data analysis and findings, conclusion and followed by limitations and suggestions.

\section{Background and literature Review}

Malaysian is an attractive destination for foreign direct investment. These international investors have demanded Malaysia business environment to give more attention on sustainability practices (Ahmad et al., 2003; Amran \& Devi, 2008; R. M. Haniffa \& Cooke, 2005; Mohd Ghazali, 2007). This demand leads Malaysian listed companies to increase their awareness on sustainability practices and its reporting. The foreign shareholding will be attracted towards companies that seriously involve in sustainability practices and this can give an international recognition (Amran \& Siti-Nabiha, 2009; Saleh, Zulkifli, \& Muhamad, 2010). In addition, Ahmad et al. (2003) and Haniffa and Cooke (2005) are of the opinion that companies having CSR disclosure with the purpose to gain public legitimation. Therefore, companies have to inform whatever sustainability practices undertaken to the society to make sure that their actions get the society's consent. According to Hooghiemstra (2000), it is noted that companies use CSR disclosure as a mean to influence public's perceptions. In addition, it is also used as a tool aimed at legitimizing the company's actions and protecting and enhancing the company's reputation and image.

Prior 2007, CSR disclosure was on voluntary basis and most of the prior studies found that the level of CSR disclosure among Malaysian listed companies was very low (Ahmad et al., 2003; Amran \& Devi, 2008; Mohd Ghazali, 2007; Smith, Yahya, \& Amiruddin, 2007). However, due to some factors, 
the CSR disclosure level is increasing over time (Amran \& Devi, 2007; Janggu, Joseph, \& Madi, 2007). Some of the factors are legislation requirement, pressure from sustainability and ethical investors (especially the foreign investors), and introduction of CSR/sustainability best practice and reporting awards, increase in economic activities and societal awareness and politics. Nevertheless, AbdMutalib et al. (2014) stated that Malaysian listed companies still have low extent and quality for the SR even it has been five years after the mandatory requirement (the sample taken for 2011). Furthermore, Ahmed (2013) found that the average extent of CSR disclosure increased to 31.71\% (2009) from $18.06 \%$ (2006), while for the average quality of CSR disclosure increased to $14.68 \%$ (2009) from 9.68\% (2006). Nevertheless, both Abd-Mutalib et al. (2014) and Ahmed Haji (2013) proved that the changes in policies have an influence on SR in Malaysia.

Even though the 2006 Bursa Listing Requirement and the revised MCCG 2007 gave some influence on SR of Malaysian listed companies, the extent and quality of SR are still low. Most probably companies were not given proper and comprehensive guidelines regarding "what" and "how" sustainability information should be disclosed. Therefore, Bursa Malaysia and Security Commission of Malaysia took some actions to raise awareness among the public listed companies by issuing "Powering Business Sustainability- A Guide for Directors" in 2010, launching the FTSE4Good Bursa Malaysia index in 2010 and amending listing requirement in 2015. In addition, companies are provided with the SRG and few toolkits as guidance to prepare their SR. Given the policy changes, Malaysia becomes the interest of this study to examine the impact of the changes on the SR among Malaysian public listed companies. Prior Malaysian studies have examined the extent and quality of sustainability information but have not taken into consideration of the recent changes.

\section{Theoretical Framework and Hypotheses Development- Resource Dependency Theory (Rdt)}

The basic proposition of resource dependence theory is the need for environmental linkages between a company and outside resources or also known as inter-organizational influence, or social control processes. This is because companies are interdependent with others when doing business transactions and other activities. Large and powerful companies might exploit their relationship with others, to ensure that other companies will comply and follow with social and environmental standards. Therefore, Pfeffer and Salancik (1978) suggested board of directors, specifically board diversity as a mechanism to minimize the interdependence issues by bringing more resources. Thus, board diversity as the focus of this study.

This study expects that the board diversity as a mechanism in minimizing the environment interdependence issues, by providing more resources for them to be or maintain sustain in the business. As further explained by Pfeffer and Salancik (1978), companies will gain four advantages from the boards of directors which are; (i) information in the form of advice or guidance, (ii) access to channels of information between company and external, (iii) preferential access to resources by obtaining commitments or support from important elements outside the company and (iv) legitimacy. All these advantages will be increased if the board is diverse.

In addition, RDT suggests the foundation for the board's function as critical resources provider to the firm including legitimacy, advice, and counsel (Hillman \& Dalziel, 2003). Thus, companies can 
better manage their sustainability issues ${ }^{2}$ with the support provided by the diverse board resources that help companies in understanding and responding to their environment efficiently (Boyd, 1990), thus improves problems solving skills as well as network connections (K. Rao \& Tilt, 2016). Next, it helps companies to better manage the sustainability issues, including addressing diverse needs of its environment and stakeholders (Bear, Rahman, \& Post, 2010). Thus, companies will have good sustainability strategies to address these needs. According to Haniffa and Cooke (2005), Corporate Social Disclosure or SR process can be perceived as a strategy of the company and the report itself as the output of the strategy. Therefore, this study proposes that board diversity has potential to make the board of directors more efficient and thus influence companies' sustainability strategies through sustainability reporting.

\section{Board Diversity and Sustainability Reporting}

The definition of board diversity as given by van Knippenberg, De Dreu and Homan (2005) is "heterogeneity among board members, and has an infinite number of dimensions ranging from age to nationality, from religious background to functional background, from task skills to relational skills and from political preference to sexual preference."

There are two categories of diversity; one that is observable or visible diversity such as race, ethnic background, nationality, gender and age, and another is less visible (educational, functional and occupational background, industry experience and organizational membership) (Kang, Cheng, \& Gray, 2007). Diversity can bring positive as well as negative effects on companies' performance (Hambrick, Cho \& Chen, 1996). Thus, the diversity (homogeneity vs. heterogeneity) is debated commonly in the diversity literature. The proponent of heterogeneity argues that the more diverse a group is, the broader perspective that allows them to be involved in in-depth conversations and generate different alternatives (Watson, Johnson, \& Merritt, 1998). The concept of diversity in the management and operational level has been widely accepted by some of listed companies and some even have Board Diversity Policy.

According to Rao and Tilt (2015), the board diversity is given enlightenment recently especially the board role has become the main issue being debated. This is because the board is akin a heart to a company, where if it is malfunction, the rest of the company will not be able to function. Zainal et al. (2013) mentioned that the board will fulfil various functions such as monitoring the management and provide resources and strategic directions to the company's operation. Therefore, the board is expected to have some characteristics that can be classified into few categories, among others, demographic characteristics, competencies, personality characteristics and values (for examples, Westphal \& Milton, 2000; Zahra \& Pearce II, 1989). After the downfalls of big and global companies, worldwide corporate governance issue has been given much limelight, especially board of directors. Though agency theory is the most frequent theory used to explain monitoring function of the board of directors, this study focuses on the RDT. Even though RDT is usually used to explain companies' performances, this study anticipates that the RDT can enlighten the relationship

\footnotetext{
${ }^{2}$ Sustainability issues include activities, initiatives, performance and strategies (reporting). Haniffa and Cooke (2005) reported that CSR Reporting was commonly reflected as a strategy, and the reporting is usually the result of strategic decision making processes.
} 
between the board of directors' characteristics and SR. Board of directors, as a resource provider mechanism will bring more resources to companies through its visible diversity (age, ethnicity and gender) or less visible diversity (skills, experiences, knowledge and etcetera), is expected to be able to help companies to be more competitive, balance the decisions and have more sustainability initiatives and strategies (Olieveira, Jonas; Lima Rodrigues, Lima; Craig, 2011; Pfeffer \& Salancik, 1978).

Moreover, Haniffa and Cooke (2005) stated that CSRR as one of the strategy and the reporting as the result of the strategic decision making processes. Therefore, CSRR will reflect the board diversity impact on the CSR decision making process. These will lead companies to disclose more on sustainability initiatives and activities. Since companies have more resources, more sustainability initiatives and activities will be performed and this will lead companies to have extensive, of high quality and easy-to- read SR. Therefore, this will shed some light on how RDT would explain the relationship between the board of director and the SR.

Good reports can possibly be produced if there is transparency/accountability which is one of important qualities of governance. It is believed that board of directors might have some influence on CSRR/SR because they play important roles in corporate governance (Rao \& Tilt, 2015). Through SR, the board of directors has to report all the initiatives and activities that have been carried out by them in order to ensure those activities are aligned with the shareholders and other stakeholders' interest as well. Being transparent, companies need to disclose what are the material matters that will affect companies' business operation as well as their surrounding (economically, environmentally and socially); and what are their action plans/activities/policies in solving the matters. In addition, their action plans/activities/policies must be aligned with the interest of shareholders. In order to ensure the company's management and operation are aligned with shareholders' interest that is maximizing shareholders' wealth; the board of director has to play a very significant role.

Board of directors is the major player in corporate governance (Rao \& Tilt, 2015). They also have to facilitate and monitor the management's effectiveness by ensuring legal compliance and preventing unlawful and improper behaviors. Therefore, public faith and confidence can be increased by having good corporate governance (Aras \& Crowther, 2008). There are many prior studies investigating the relationship between the board attributes and board diversity on many corporate disclosure including SR (Amran, Lee, \& Devi, 2013; Barakat, López Pérez, \& Rodríguez Ariza, 2014; Jia \& Zhang, 2012; Khan, 2010; Oba \& Fodio, 2012; Prado-Lorenzo, Gallego-Alvarez, \& Garcia-Sanchez, 2009; Rao, Tilt, \& Lester, 2012). Furthermore, some variables that represent board diversity, have been tested such as gender diversity (Oba \& Fodio, 2012; gender composition (Fernandez-Feijoo, Romera, \& Ruiz, 2012); ethnic societal values and religion (Haniffa \& Cooke, 2002).

\section{Hypothesis Development}

As mentioned above that RDT states that board diversity can be a good mechanism to link a company to its external environment and attain resources. With the advantages brought by the board diversity as mentioned above, this study believes that, board diversity (in age, ethnic, gender and director resource diversity) will enhance the sustainable strategies of the companies and help the board in addressing different needs of the environment, stakeholders as well as users of the SR. Thus, the diverse board would help in making the SR more extensive and of high quality. 


\section{Gender Diversity and SR}

Having gender diversity in the boards will bring some balanced decision because women think differently from men. In addition they are more sensitive with sustainability issues, more generous towards communities and pay more attention to stakeholders especially such as communities, employees and environment. Hillman, Canella, and Harris (2002) stated that women director more likely to offer different viewpoints to the board because they tend to have expert backgrounds outside business. Thus, they will balance and support effective decision making which enhance the sustainability strategies of the business. With all the attributes mentioned above, female board members contribute towards enhancing sustainability strategies and in turn improve SR. Moreover, In Al-Shaer and Zaman (2016), they find that gender diversity (measured by number of female board members and independent female board member) is positively associated with the SR among 333 companies listed in 2012 in the UK FTSE350. While Barako and Brown (2008) report that the increased women representation on the board of directors of Kenyan's banks makes significant and positive association with the level of voluntary corporate social reporting among Kenya listed companies. Therefore, the first hypothesis is:

$H$ 1. There is a significant difference in the extent and quality of SR between companies that have female board members and companies that do not have female board members.

\section{Age Diversity and SR}

As stated in Hafsi and Turgut (2013), directors' business experience and knowledge can be reflected by their ages which also as an indication of their maturity in leading the direction of the businesses. Age diversity is an important element in board attributes because the same age group of board members might bring biasness in the leadership and the decision-making styles of the board (Abdullah \& Ismail, 2013). As in sustainability area, some studies claim that older directors will have more concern on corporate social activities of companies because age reflects directors' experiences and maturity in business (Hafsi \& Turgut, 2013; Post, Rahman, \& Rubow, 2011). Further, according to Kets de Vries and Miller (as cited in Hafsi \& Turgut, 2013), older directors tend to be more sensitive towards society issues and willing to contribute more for its welfare. In relation to reporting, even though there is lack of studies that concern on the impact of age and reporting, some results appear to approve a positive relationship (Rao \& Tilt, 2015). Post et al. (2011) find companies whose boards members' average age closer to 56 years, will disclose more on environmental corporate social responsibility (ECSR) governance. More maturity, experiences, concerns, sensitive toward society issues, all these attributes will provide the board with various perceptions, ideas and suggestions which help the board to enhance sustainability strategies. In turn, it helps to improve the SR. Thus, the second hypothesis is:

$H$ 2. There is a significant difference in the extent and quality of SR between companies that board members' average age diversity is below and above sixty years old. 


\section{Ethnic Diversity and SR}

There are three main ethnics in Malaysia society which are Malay, Chinese and Indians. According to Hofstede (1984), an individual from one group can be distinguished from another individual from other group through culture. As mentioned by Harris (as cited in Hamzah et al., 2015), the learning, social traditions, way of life, thought process, feelings and behavior of individuals can be reflected by the culture. Malaysia has multi-cultures community and it give the best platform for this study. In regards to studies that examine the relationship between the board ethnicity background and CSR, the results are inconsistent. Therefore, board members who come from different ethnics will provide resourceful ways of thinking, cultural belief and attitudes which will help companies in their sustainability strategies and SR. Therefore, the second hypothesis is:

$H$ 3. There is a significant difference in the extent and quality of SR among companies that have ethnic diversity below 0.5 and companies that have ethnic diversity equal or greater than 0.53 .

\section{Research Design Unit/Methodology}

\section{Population, sample selection and unit of analysis}

In October 2015, Bursa Malaysia launched the Sustainability Reporting Framework that comprises Sustainability Reporting Guide (SRG), Sustainability Law and Sustainability Toolkit. The SR disclosure obligation will take effect in three stages. In the first stage, companies whose market capitalization (excluding treasury shares) is of RM2 billion and above as at 31 December 2015; or as at the date of its listing in 2016, shall disclose their SR (with the new guidelines) in companies annual report on or after 31 December 2016. For the purpose of this study, the sample comprises of companies that fall under the first stage only. The total companies that fulfill this condition are 102 companies and the final number is 98 companies (refer Table 1). Since not all the sample companies' year end is on 31 December, therefore, the annual reports taken for the study is on 31 December 2016 onwards. Additionally, in this study, SR covers all narratives sections (non-financial sections) in the annual report since some of the sustainability information is disclosed in other section than the SR section.

Table 1. Sample

\begin{tabular}{|c|c|c|}
\hline & & $\mathrm{N}$ \\
\hline \multicolumn{2}{|c|}{ Companies that fall under first stage condition } & 102 \\
\hline \multirow[t]{4}{*}{ Less: } & Companies that being delisted & 2 \\
\hline & $\begin{array}{l}\text { Having an unfriendly user format of annual } \\
\text { report }\end{array}$ & 1 \\
\hline & Bursa Malaysia Bhd (the regulator) & 1 \\
\hline & Final & 98 \\
\hline
\end{tabular}




\section{Measurement of the Dependent and Independent Variables: Dependent Variables}

Sustainability Reporting (SR) is the dependent variable of this study. SR can be represented by the extent (SREXT) and quality (SRQLTY) of sustainability information. In order to measure the extent and quality of SR, a disclosure index ${ }^{3}$ is used. Previously, there are various disclosure indexes to measure the extent and quality of CSR disclosure which are adapted from previous studies. However, this study uses the disclosure index suggested by SRG with addition on governance items taken from Sutantoputra (2009).

In this study, the extent of sustainability information is defined as how much the information disclosed matched with the disclosure checklist. The extent of SR can be measured by two techniques (Al-Tuwaijri, Christensen, \& Hughes, 2004). The first technique is through the measurement of level of quantity of sustainability information disclosed. The measures are taken from the number of pages (Gray, Kouhy, \& Laver, 1995; Guthrie \& Parker, 1989), number of sentences (Hackston \& Milne, 1996) and number of words (Abd-Mutalib et al., 2014; Deegan \& Gordon, 1996; Zeghal \& Ahmed, 1990). However, these measures have some limitations. According to Al-Tuwaijri et al. (2004), pictures which has no environmental and social information, may be included when counting the pages, while sentences and words may disregard essential graphs, tables and charts. Moreover, some companies might be likely to develop good impression by disclosing more pages and thicker reports. The second technique is by computing the disclosure-scoring index through content analysis method. Under this technique, researchers identify sustainability issues and then apply the list to content analysis using the binary coding technique. A score of ' 1 ' is awarded if an item disclosed and ' 0 ' if it is not. Later, the aggregate score for each company is computed. Thus, the extent of SR is measured as follows:

$$
\operatorname{SREXT} j=\frac{\sum_{t=1}^{n} X_{i j}}{n_{j}}
$$

$\begin{array}{ll}\text { SREXT } & =\text { SR extent score for } j^{\text {th }} \text { company } \\ n_{j} & =\text { total number of items expected for } j^{\text {th }} \text { company with maximum score } \\ & \text { assigned } \\ & =1 \text { if ith (relevant) item disclosed, } \\ & =0 \text { if ith (relevant) item not disclosed, } \\ & \text { so that } 0<\text { SREXTj< } 1\end{array}$

The quality of sustainability information refers to how the sustainability information is disclosed. Is it being disclosed briefly, qualitatively and details explanation or quantitatively? Thus, the quality score will be determined in the same way as the extent score except that the information disclosed is given different weights. In addition, the quantitative information disclosed is given more weight than the qualitative information because it is more objective and informative (Al-Tuwaijri et al., 2004). Thus, this study applies the same technique with Al-Tuwaijri et al. (2004); Cooke (1989);

\footnotetext{
3 This study the disclosure checklist provided in the Sustainability Reporting Guide (SRG).
} 
Hackston and Milne (1996); Hughes et al.(2001) and Ahmed Haji (2013). The score and quality definition are summarized in Table 2 . The quality of SR is measured as follows:

$$
\begin{array}{ll}
\qquad \operatorname{SRQLTY} j=\frac{\sum_{t=1}^{n} X_{i j}}{n_{j}} \\
\text { SRQLTY } & =\text { SR quality score for } j^{t h} \text { company } \\
n_{j} & \text { total number of items expected for } j^{t h} \text { company with maximum score } \\
& \text { assigned } \\
= & \text { the score of } 3 \text { for the ith item if quantitative data is disclosed, the score of } 2 \text { for } \\
& \text { the } i \text { ith item if qualitative data with specific explanation is disclosed, the score } \\
& \text { of } 1 \text { for the ith item if general qualitative data is disclosed and the score of } 0 \\
& \text { for the ith item if there is no disclosure. }
\end{array}
$$

Table 2. Quality Score

\begin{tabular}{|l|l|}
\hline Quality of disclosure & Quality definition \\
\hline $0=$ non-disclosure & $\begin{array}{l}\text { do not disclose any information for the given } \\
\text { items }\end{array}$ \\
\hline 1= general qualitative disclosure & common qualitative disclosures \\
\hline $\begin{array}{l}2=\text { qualitative disclosure with specific } \\
\text { explanation }\end{array}$ & $\begin{array}{l}\text { non-quantitative but specific information } \\
\text { related to these items }\end{array}$ \\
\hline $3=$ quantitative disclosure & $\begin{array}{l}\text { quantitative disclosures related to the items as } \\
\text { described in the SR checklist. }\end{array}$ \\
\hline
\end{tabular}

(Source: Cooke, 1989)

\section{Independent variables}

\section{Age Diversity}

Abdullah and Ismail (2013) examined the influence of BOD (gender, ethnic and age) on companies' performance among Malaysian listed companies. Even though the current study will examine almost the same BOD, but this study only adopts the measurement of age diversity. First, the average age of the board's members is determined. Further, as stated by Abdullah and Ismail (2013), the board's members should not primarily comprise of those who are nearly retirement age. Besides, Higgs Report (2003) defines directors who are almost at retirement age in United Kingdom public listed companies as unproductive. Consequently, this study defines nearing retirement age as being 60 years and above. Therefore, the board of director is given " 0 " value and considered as unproductive if the average age of the board's members is 60 and above, whereas, if the average age of the board's members is below 60 , it will be considered as productive and given " 1 ".

\section{Ethnic Diversity}

In order to measure ethnic diversity, the current study uses the Blau index. The Blau index is an index of heterogeneity (Blau, 1977; as cited in Zhang, 2012). If the score is zero, it indicates a perfectly homogeneous group and a score of 1 indicating a perfectly heterogeneous group. The higher score indicates more ethnic diversity. The score, it will be computed as the difference between 
INTERNATIONAL JOURNAL OF ACADEMIC RESEARCH IN BUSINESS AND SOCIAL SCIENCES

Vol. 9, No. 3, March, 2019, E-ISSN: 222 2-6990 @ 2019 HRMARS

1 and the sum of the proportion of unit member $p$ in each of the $k$ th categories that compose the group. The index is then categorized into two categories; "0" if the score $<0.5$; " 1 " if the score $\geq 0.5$.

\section{Table 3. Blau Index formula}

\begin{tabular}{|l|l|}
\hline Diversity & $=1-\sum(\mathrm{pk})^{2}$ \\
\hline
\end{tabular}

\section{Gender Diversity}

There are various measurements for gender diversity used in previous studies such as the number of female directors on the board (Al-Shaer \& Zaman, 2016) and the proportion/percentage of female directors on the board (Al-Shaer \& Zaman, 2016; Boulouta, 2013). However, due to the small number of female directors in the board which may affect statistical tests, some studies use categorical. For example, in Abdullah and Ismail (2013) and Rose (2007) they use dummy variable equal to one if there is at least one woman on the board, otherwise it equals zero. Even though Malaysian government had extended the policy of $30 \%$ women involvement in making decision at top management level to listed companies in 2011, until now, the number is not achieved. The average of female director in the Malaysian listed companies' board as at September 2016 was $11.8 \%$ across 800 over companies as stated by Anne Abraham at MIM-KAS Women in Leadership Forum ${ }^{4}$. Due to the above explanation, the current study uses the dichotomous measurement where the company is given " 1 " if there is at least one female director in the board of directors and " 0 " if there is none. The table below shows the summary of the independent variables and its measurement. The study uses Statistical Package for the Social Sciences (SPSS) for descriptive analysis. Furthermore, the study uses independent t-test in order to test the hypotheses.

Table 3. Independent variables

\begin{tabular}{|l|l|l|}
\hline $\begin{array}{l}\text { Gender } \\
\text { (GEN) }\end{array}$ & $\begin{array}{l}\text { The measurement } \\
\text { Gender = gender diversity, a } \\
\text { dummy variable; "1" if at least } \\
\text { one female director on the } \\
\text { board, and "0" otherwise, }\end{array}$ & $\begin{array}{l}\text { (Abdullah \& Ismail, 2013; Rose, } \\
\text { 2007) }\end{array}$ \\
\hline $\begin{array}{l}\text { Age } \\
\text { (AGE) }\end{array}$ & $\begin{array}{l}\text { Age }=\text { age diversity, a dummy } \\
\text { variable; "1" if the average age } \\
\text { of the board of directors <60 } \\
\text { years, and "0" if the average } \\
\text { age of the board of directors } \geq \\
60 \text { years. }\end{array}$ & (Abdullah \& Ismail, 2013) \\
\hline $\begin{array}{l}\text { Ethnicity } \\
\text { (ETHN) }\end{array}$ & $\begin{array}{l}\text { Diversity } \\
\text { (Blau index). The index is then } \\
\text { categorized into two } \\
\text { categories; "0" if the score <0.5 }\end{array}$ & (Bear et al., 2010) (Zhang, 2012) \\
\hline
\end{tabular}

\footnotetext{
${ }^{4}$ Anne Abraham is a chairman of LeadWomen, an organization that supports women's career goals and aspirations. The Malaysian Institute of Management (MIM) in collaboration with Konrad Adenauer Stiftung (KAS) and National Council of Women's Organisations' (NCWO) is proud to organise the MIM-KAS Women in Leadership Forum on 23 December 2016.
} 
INTERNATIONAL JOURNAL OF ACADEMIC RESEARCH IN BUSINESS AND SOCIAL SCIENCES

Vol. 9, No. 3, March, 2019, E-ISSN: 222 2-6990 @ 2019 HRMARS

\begin{tabular}{|l|l|l|}
\hline & $\begin{array}{l}\text { (Low); "1" if the score } \geq 0.5 \\
\text { (High) }\end{array}$ & \\
\hline
\end{tabular}

\section{Results and Discussion}

In panel A of Table 4, it shows the overall descriptive analysis for SR in term of the extent (SREXT) and quality (SRQLTY) of sampled companies. It shows the minimum score for the SREXT among Malaysia listed companies is $1.5 \%$ while the maximum score is $76.8 \%$. The average score for SREXT is $40.7 \%$ which indicates the extent of SR among Malaysian listed companies is still below $50 \%$. However, this average score of SREXT shows an increase in the extent of SR among Malaysian listed companies compared to the study by Ahmed Haji (2013) who find the average score of the extent of SR in 2009 (3 years after the mandatory requirement by Bursa Malaysia) as $31.71 \%$. Even though companies are given CSR framework as guideline, but there is a flexibility for the companies to choose "what" and "how" sustainability information to be disclosed, which results in low extent of SR (Ahmed Haji, 2013). The increase in the average score for SREXT in this study may probably because of the comprehensive guideline provided by Bursa Malaysia, the SRG. Even though sustainability disclosure has become a mandatory requirement in Malaysia, the regulatory body cannot ensure the extensiveness of a report. Nevertheless, companies are still having their discretions in deciding on sustainability information materiality and scope. For example, in disclosing the amount of electricity consumption, some companies decide that it is not material information and they do not disclose it. In addition, companies can decide the reporting scope of SR. For example, if a company operates in a few countries or business operations, and the company is having some sustainability issues in one of the country or its operations, then it can decide that the scope of its SR will not cover those problem areas and explanations must be provided to the regulatory.

Pertaining to the SRQLTY, the minimum is $1.5 \%$ which is better than Abd-Mutalib et al. (2014) who find at least one company did not disclose any SR at all. Even though their maximum score is $84 \%$ which is higher than our finding, $68.2 \%$, on average our finding is better than Abd-Mutalib et al. (2014) which is $31.6 \%$ and $14.5 \%$ respectively. Even though their samples are taken five years after the mandatory requirement, their average is far behind. However Ahmed Haji (2013) finds the average score of quality of SR as $14.68 \%$ which is a slight increase compared to Abd-Mutalib et al. (2014). According to Zainal et al. (2013a) who examine the quantity/extent and quality of Corporate Social Responsibility Reporting (CSRR) among Malaysian listed companies for a period of five years (pre and post mandatory requirement), it shows that companies are reporting their CSR information more in year 2007 (CSRR mandatory requirement took effect). It would be appeared that the increase in the current study findings in the extent and quality of SR, may probably due to the SRG issued by Bursa Malaysia that gives clearer guidelines to companies in disclosing and presenting their sustainability information in annual reports.

The increase in both the extent and quality of SR in this study seems to suggest that the changes in business environment do influent the manner of disclosing of sustainability information among Malaysian listed companies. The average score of SREXT is higher than the average score of SRQLTY in this study which are $40.7 \%$ and $31.6 \%$ respectively. It indicates that Malaysian listed companies are disclosing more items as on the disclosure index. However, the quality of information is low. The mean score indicated that companies disclosed mainly on general/common qualitative 
disclosure of information ${ }^{5}$ (refer Table 2). Most probably because the information is either not disclosed at all or the information is too brief and more on qualitative in nature. They are lacking of quantitative information and this may due to three possible reasons. First, awareness and understanding on the sustainability concept among the employees are still low especially the operations employees. Thus, it is hard to get their corporation to support sustainability agenda of the company. Second, they may have problem in information management where it is hard to gather all the sustainability information accurately and valid. Most companies are having operations in various places and gathering information is not an easy work. Lastly, this is the first year of the amended listing requirement and SRG implementations, therefore companies are still in the learning and adapting process. However, this study believes that in the coming years to come, Malaysian listed companies may improve their SR since the sample companies taken are in their first year of the SRG implementation.

Table 4. Descriptive statistics for the extent and quality of SR.

\begin{tabular}{|l|c|c|c|c|c|c|}
\hline Panel A & N & Mean & $\begin{array}{c}\text { Media } \\
\mathrm{n}\end{array}$ & Stdv & Min & Max \\
\hline SREXT & 98 & 0.407 & 0.400 & 0.170 & 0.015 & 0.768 \\
\hline SRQLTY & 98 & 0.316 & 0.313 & 0.149 & 0.015 & 0.682 \\
\hline Valid N (listwise) & & & & & \\
\hline Panel B- SREXT & 12 & 0.4 & 0.431 & 0.117 & 0.2 & 0.523 \\
\hline $\begin{array}{l}\text { Construction/real } \\
\text { estate }\end{array}$ & 12 & 0.318 & 0.328 & 0.193 & 0.015 & 0.746 \\
\hline Consumer goods & 14 & 0.479 & 0.432 & 0.133 & 0.318 & 0.75 \\
\hline Finance & 10 & 0.344 & 0.379 & 0.149 & 0.046 & 0.591 \\
\hline Manufacturing & 9 & 0.463 & 0.562 & 0.217 & 0.055 & 0.685 \\
\hline Plantation & 2 & 0.594 & 0.594 & 0.246 & 0.42 & 0.768 \\
\hline Oil and gas & 5 & 0.364 & 0.339 & 0.213 & 0.143 & 0.625 \\
\hline $\begin{array}{l}\text { Telecommunicatio } \\
\mathrm{n}\end{array}$ & 3 & 0.418 & 0.418 & 0.075 & 0.343 & 0.493 \\
\hline Utilities & 30 & 0.406 & 0.386 & 0.171 & 0.068 & 0.75 \\
\hline $\begin{array}{l}\text { Trading and } \\
\text { services }\end{array}$ & 12 & 0.312 & 0.341 & 0.116 & 0.133 & 0.462 \\
\hline Panel C- SRQLTY & & & & & & \\
\hline $\begin{array}{l}\text { Construction/real } \\
\text { estate }\end{array}$ & 12 & & & & & \\
\hline
\end{tabular}

\footnotetext{
$531.6 \% \times 3$ (maximum score of quality) $=0.948$. This indicated that most of the information disclosed was general/common qualitative information.
} 
INTERNATIONAL JOURNAL OF ACADEMIC RESEARCH IN BUSINESS AND SOCIAL SCIENCES Vol. 9, No. 3, March, 2019, E-ISSN: 222 2-6990 @ 2019 HRMARS

\begin{tabular}{|l|c|c|c|c|c|c|}
\hline Consumer goods & 12 & 0.238 & 0.236 & 0.158 & 0.015 & 0.582 \\
\hline Finance & 14 & 0.367 & 0.379 & 0.128 & 0.197 & 0.576 \\
\hline Manufacturing & 10 & 0.261 & 0.288 & 0.134 & 0.03 & 0.485 \\
\hline Plantation & 9 & 0.368 & 0.365 & 0.196 & 0.05 & 0.616 \\
\hline Oil and gas & 2 & 0.507 & 0.507 & 0.198 & 0.367 & 0.647 \\
\hline $\begin{array}{l}\text { Telecommunicatio } \\
\mathrm{n}\end{array}$ & 5 & 0.293 & 0.286 & 0.177 & 0.101 & 0.518 \\
\hline Utilities & 3 & 0.348 & 0.323 & 0.08 & 0.284 & 0.438 \\
\hline $\begin{array}{l}\text { Trading and } \\
\text { services }\end{array}$ & 30 & 0.316 & 0.288 & 0.149 & 0.061 & 0.682 \\
\hline
\end{tabular}

Further, regarding the analysis of the extent of SR among industries, panel B shows that companies in oil and gas industry score the highest extent mean of $59.4 \%$, followed by finance with the mean score of $47.9 \%$ and plantation mean score is $46.3 \%$. While the lowest extent mean is marked by consumer goods industry which is $31.8 \%$. It is no surprise companies in the oil and gas industry scores the highest of SREXT which means that they disclose more items in the disclosure index than any companies from other industries. This most probably because they are pressured by the investors and campaigners to disclose sustainability information (KPMG, 2017)(KPMG, 2017)(KPMG, 2017)since this industry's operations have high potential positive and negative impact on sustainable development areas including communities, ecosystem and economies (UNDP, IFC, \& IPIECA, 2018). In addition, it appears that companies in finance industry are taking serious consideration in their SR until one of them won platinum medal for the best CSR reporting award in 2016 (NACRA 2016). In addition, Chih, Chih, and Chen (2010) concluded in their studies on CSR among financial industry, that financial firms in countries with stronger levels of legal enforcement tend to engage in more CSR activities.

In regards to the quality of SR, the results in panel $C$ exhibit lesser scores among the industries. Companies in the oil and gas industry still show the highest quality mean score of $50.7 \%$ followed by companies in plantation industry which is $36.8 \%$ and finance industry mean score is $36.7 \%$. The poorest quality of SR is marked by companies in manufacturing industry with the score of $26.1 \%$. The results show that these industries disclose less quantitative information in their SR. 
INTERNATIONAL JOURNAL OF ACADEMIC RESEARCH IN BUSINESS AND SOCIAL SCIENCES Vol. 9, No. 3, March, 2019, E-ISSN: 222 2-6990 @ 2019 HRMARS

Table 5. The table shows the independent t-test for gender, age diversity and ethnic diversity.

\begin{tabular}{|c|c|c|c|c|c|c|c|c|c|}
\hline \multicolumn{10}{|l|}{ Independent t-test } \\
\hline SREXT & $\mathbf{N}$ & Mean & $\begin{array}{l}\text { t- } \\
\text { value }\end{array}$ & $\begin{array}{l}p- \\
\text { value }\end{array}$ & SRQLTY & $\mathbf{N}$ & Mean & $\begin{array}{l}\text { t- } \\
\text { value }\end{array}$ & $\begin{array}{l}p \text { - } \\
\text { value }\end{array}$ \\
\hline \multicolumn{2}{|l|}{ Gender Diversity } & & -2.517 & 0.013 & Gender Diversity & & & $\begin{array}{c}- \\
1925\end{array}$ & 0.057 \\
\hline $\begin{array}{l}\text { there is female } \\
\text { board members }\end{array}$ & $\begin{array}{l}8 \\
1\end{array}$ & 0.426 & & & $\begin{array}{l}\text { there is female } \\
\text { board members }\end{array}$ & 81 & 0.329 & & \\
\hline $\begin{array}{l}\text { no female board } \\
\text { members }\end{array}$ & $\begin{array}{l}1 \\
7\end{array}$ & 0.315 & & & $\begin{array}{l}\text { no female board } \\
\text { members }\end{array}$ & 17 & 0.254 & & \\
\hline Age Diversity & & & -1.307 & 0.194 & Age Diversity & & & $\begin{array}{c}- \\
1.148\end{array}$ & 0.254 \\
\hline $\begin{array}{l}\text { average age }<60 \\
\text { years }\end{array}$ & $\begin{array}{l}3 \\
9\end{array}$ & 0.434 & & & $\begin{array}{l}\text { average age }<60 \\
\text { years }\end{array}$ & 39 & 0.338 & & \\
\hline $\begin{array}{l}\text { average age } \geq 60 \\
\text { years }\end{array}$ & $\begin{array}{l}5 \\
9 \\
\end{array}$ & 0.389 & & & $\begin{array}{l}\text { average age } \geq 60 \\
\text { years }\end{array}$ & 59 & 0.302 & & \\
\hline Ethnic Diversity & & & -1.130 & 0.261 & Ethnic Diversity & & & $\begin{array}{l}- \\
1.205\end{array}$ & 0.231 \\
\hline diversity <.5 (Low) & $\begin{array}{l}5 \\
8\end{array}$ & 0.391 & & & diversity <.5 (Low) & 58 & 0.301 & & \\
\hline $\begin{array}{l}\text { Diversity } \geq 0.5 \\
\text { (High) }\end{array}$ & $\begin{array}{l}4 \\
0\end{array}$ & 0.430 & & & $\begin{array}{l}\text { diversity } \geq 0.5 \\
\text { (High) }\end{array}$ & 40 & 0.338 & & \\
\hline
\end{tabular}

Independent sample t-tests were carried out to determine if there were significant differences in the extent and quality of SR between the groups of independent variables. Table 5 shows results of all t-test involving gender, age and ethnic diversity. Out of the three independent variables, only gender diversity shows significant difference in the extent and slightly significant in quality of SR. The result shows that, companies which have female director on board have greater mean score for SREXT (M=42.6\%) and SRQLTY ( $M=32.9 \%)$ than companies that have no female director (SREXT M=31.5\% and SRQLTY M=25.4\%). Companies with female directors on the board have higher score for both extent and quality. The difference between the two group for SREXT is statistically significant at $5 \%(t=-2.517, p=0.013)$, but it is slightly significant for SRQLTY where $t=-$ 1.925, $\mathrm{p}=0.057$ respectively). Therefore, $\mathrm{H} 1$ is supported for the extent but not the quality. It indicates that companies that have female board members tend to have more extensive and quality SR. It implies that women are more concern and sympathy on sustainability issues. The result supports the finding by and Barako and Brown (2008). Fernandez-Feijoo et al. (2012) reported that company that has at least three female directors tends to disclose high quality sustainability information and assurance statements. In addition Barako and Brown (2008) provide evidence that female directors have significant and positive association with corporate social reporting. Impliedly, the existence of female directors in companies' board of director can improve a company SR.

Regarding the age diversity, the test shows that there is no significant difference in the mean score of SR (both SREXT and SRQLTY) between the companies that have average age of board members below sixty years and the companies that have average age of board members equal or 
greater than sixty years. The results are not significant as both (SREXT and SRQLTY) $p$ value ( $p=0.194$ and $p=0.254$ ) are greater than 0.05 . Thus $\mathrm{H} 2$ is not supported. It means that neither companies that have board members average age is below sixty years nor greater than sixty years, report SR extensively and of high quality of sustainability information. Even though some researchers claim that older directors will become more conscious on sustainability of companies because age reflects directors' experiences and maturity in business (Hafsi \& Turgut, 2013; Post et al., 2011), but age of board members has no impact on SR in this study. However, the average score of SREXT and SRQLTY is higher in companies that have average age of board members below sixty years (SREXT M=43.4\%, SRQLTY M=33.8\%) than companies that have average age of board members equal or greater than sixty years(SREXT M=39.9\%, SRQLTY M=31.4\%).

Concerning the ethnic diversity, there is no significant difference in the mean score of SR (both SREXT and SRQLTY) between companies that have low ethnic diversity (SREXT M=39.1\%, SRQLTY $M=30.1 \%$ ) and high ethnic diversity (SREXT $M=44.4 \%$, SRQLTY $M=35.4 \%$ ). The result are not significant for both SREXT and SRQLTY where the $p$-value are greater than $0.05(p=0.26145$ and $\mathrm{p}=0.231$ respectively). Thus, $\mathrm{H} 3$ is not supported. It seems that companies that have board of director that comprises of various ethnic members would not report differently in terms of extent and quality of sustainability information. Even though Malaysia has special multi-races community, it seems like it does not give any significant difference in SR. However, Hamzah et al. (2015) find that Malays and India ethnic can influence significantly the disclosure level of intellectual capital in annual report.

Even though RDT stated that diverse board of directors I bring more resources to companies, it appears in this study that only the gender diversity is proven. It proves that female directors bring diverse background, different values and perceptions on sustainability, access to information, experience, expertise and etcetera. Therefore female directors are more committed to sustainability of the companies (Fernandez-Feijoo et al., 2012). All these values will help female directors in giving balance strategic decision-making process which can be reflected in the SR. With the diverse values, female directors help companies to have more sustainability initiatives and activities which will be reported in their SR. In contrast, age diversity and ethnic diversity are not proven to be significant in bringing more resources to the companies' sustainability initiative and activities. However, Hafsi and Turgut (2013) found age diversity had significant negative relationship with the social performance which was contradict with their assumption. They stated that age may possibly lead to polarization, which may cause the curvilinear effect of age. Regarding the ethnic diversity, the study found no evidence which was contradict with Haniffa and Cooke (2005) who found that ethnic diversity was significantly affect the CSR disclosure. Though board diversity is believed to help companies in their business operation, but it is not fully supported in this study. Maybe it is more on the less observable diversity that give impact on SR rather than the demographic diversity.

\section{Conclusion}

The first aim of the current study is to examine the extent and quality of SR among Malaysian listed companies after the implementation of SRG by the Bursa Malaysia. With the guideline provided by Bursa Malaysia for companies to prepare SR, it is expected that SR of Malaysian listed companies will be more comprehensive and of good quality. However, contrary to expectation, the overall mean scores for the extent and quality of SR is low of $40.7 \%$ and $31.6 \%$ respectively. It would appear that even though it was mandatory for these companies to provide sustainability information in corporate 
annual reports, on average companies disclosed less than half of the disclosure checklist. These findings may be attributable to a number of factors. Firstly, the sample companies in this study were the first batch to comply with the amended listing requirement and SRG. The SRG was launched on October 2015 and the effective date to comply was 31 December 2016 onwards. Thus, some companies may be facing problems in understanding the SRG and collecting the related information and data within one year. It is hard to collect the quantitative data within one year. Some examples of quantitative data (which carries more weighted quality score) are how many tones greenhouse gas emission, how many cubic meters of recycled water consumption, how much kilojoule energy consumption and etcetera. As a result, their reporting is very much in narrative/qualitative information which leads to lower quality score of SR. However, the score is expected to increase in years to come as companies may have proper mechanisms to gather all the necessary quantitative sustainability data.

The second explanation is the concept of materiality. It is a company's discretion to classify some information as material or not. If it is material then it will be disclosed in SR. For example, water consumption might be perceived as immaterial to some companies, thus the information of water consumption would not be disclosed in SR, whereas, if energy consumption is considered material, then it will be disclosed in SR. The last possible explanation is some companies disclose little sustainability information in their annual report because they will disclose sustainability information in details somewhere such as stand-alone SR or companies' website. Among industries, it seems like companies are still having different reaction towards reporting their sustainability activities and initiatives in SR even though it is a mandatory requirement. Some are having very good SR until it can win some awards such as NACRA and MaSRA. As expected, companies from oil and gas, manufacturing and plantation industry had extensive and good quality of SR except manufacturing industry. However, companies from finance industry score the second highest extent of SR may due to their awareness and wise act in communicating their sustainability information to stakeholders. Besides, they are strictly regulated and under purview of Bank Negara Malaysia (Abd-Mutalib et al., 2014).

The second aim of this study is to examine the difference in mean score of the extent and quality of SR between different board diversity groups. Even though the studies on board diversity and $S R$ is limited, board diversity is still perceived to enhance independence, increase board effectiveness, creativity, innovation and quality decision making pertaining to sustainability matters. Some listed companies do have board diversity policy. However, the current study only supported the gender diversity impact that it did improve the extent and quality of SR, but not the age and ethnic diversity. The age and ethnicity diversity of board members do not give any influence in SR. This study is an attempt to apply the RDT in explaining the impact of board diversity on corporate reporting. Boards of directors as a mechanism that bring more resources and are expected to be able to help companies to be more competitive, balance the decisions and have more sustainability initiatives and strategies (Olieveira, Jonas; Lima Rodrigues, Lima; Craig, 2011; Pfeffer \& Salancik, 1978). Moreover, Haniffa and Cooke (2005) stated that CSRR as one of the strategy and the reporting as the result of the strategic decision making processes. Therefore, CSRR will reflect the board diversity impact on the CSR decision making process. Thus, this study manages to find evidence that gender diversity could bring some impact in SR. 


\section{Limitation and suggestions}

There are always limitations in every study and so does this study. First, since the samples companies are in the first year of implementing the amended listing requirement and SRG, this study only considered the first batch of companies whose market capitalization are RM2 billion and above (on 31 December 2015) which comprises of only 102 companies. There are another 2 batches which are not included in this study. Therefore, it would like to suggest for the future study to consider the second and last batch. The results may be different due to different market sizes. In addition, they are probably more prepared and understand the requirements pertaining to SR. Secondly, this study only examined limited demographic diversity (observable diversity) which are age, ethnic and gender. However there are other less observable diversities such as skills, knowledge, and experience, professional and educational background which may give impact on the SR. Thus, this study would like to suggest for the future research to examine these diversities as independent variables that may impact the SR. It may not the age and ethnic diversity of the board members that give impact on SR but rather their capacity, ability, potential and etcetera. Finally, there are other mediums used by companies in disseminating their sustainability information such as stand-alone SR, companies' website and pamphlets. It is a limitation of this study for it only examined companies' annual reports that may provide a small portion of sustainability information. Nevertheless, as highlighted by Guthrie and Parker (1989) and Said et al. (2009), companies use annual report as one of its sole communication tool towards their stakeholders because of its high credibility (Tilt, 1994). Besides it was found that annual report is more important source of information than others (Deegan \& Rankin, 1997) and it is produced every year and conveniently available (Said et al., 2009).

\section{Acknowledgement}

This research was supported by IIUM Accounting Research And Education Fund Research Project IAREF.

\section{Corresponding Author \\ Name : Aishah Sheikh Abu Bakar \\ Affiliation : Jabatan Pengajian Politeknik dan Kolej Komuniti \\ Country : Malaysia \\ Email : aishah.sheikhabubakar@gmail.com}

\section{References}

Abd-Mutalib, H., Jamil, C. Z. M., \& Wan-Hussin, W. N. (2014). The availability, extent and quality of sustainability reporting by Malaysian listed firms: subsequent to mandatory disclosure. Asian Journal of Finance \& Accounting, 6(2), 239-257. https://doi.org/10.5296/ajfa.v6i2.6108

Abdullah, S. N., \& Ismail, K. N. I. K. (2013). Gender, ethnic and age diversity of the boards of large Malaysian firms and performance. Jurnal Pengurusan, 38, 27-40.

Ahmad, N. N. N., Sulaiman, M., \& Siswantoro, D. (2003). Corporate social responsibility disclosure in Malaysia: An analysis of annual reports of KLSE listed companies. IIUM Journal of Economics and Management, 11(1), 1-37. Retrieved from https://www.academia.edu/4855752/CORPORATE_SOCIAL_RESPONSIBILITY_DISCLOSURE_IN_ MALAYSIA_AN_ANALYSIS_OF_ANNUAL_REPORTS_OF_KLSE_LISTED_COMPANIES 
INTERNATIONAL JOURNAL OF ACADEMIC RESEARCH IN BUSINESS AND SOCIAL SCIENCES

Vol. 9, No. 3, March, 2019, E-ISSN: 222 2-6990 @ 2019 HRMARS

Ahmed Haji, A. (2013). Corporate social responsibility disclosures over time: evidence from Malaysia. Managerial Auditing Journal, 28(7), 647-676. https://doi.org/10.1108/MAJ-07-20120729

Al-Shaer, H., \& Zaman, M. (2016). Board gender diversity and sustainability reporting quality. Journal of Contemporary Accounting and Economics, 12(3), 210-222. https://doi.org/10.1016/j.jcae.2016.09.001

Al-Tuwaijri, S. A., Christensen, T. E., \& Hughes, K. E. (2004). The relations among environmental disclosure, environmental performance, and economic performance: A simultaneous equations approach. Accounting, Organizations and Society, 29(5), 447-471. https://doi.org/10.1016/S0361-3682(03)00032-1

Amran, A., \& Devi, S. S. (2007). Corporate social reporting in Malaysia : A political theory. Malaysian Accounting Review, 6(1), 19-44.

Amran, A., \& Devi, S. S. (2008). The impact of government and foreign affiliate influence on corporate social reporting: The case of Malaysia. Managerial Auditing Journal, 23(4), 386-404. https://doi.org/10.1108/02686900810864327

Amran, A., Lee, S. P., \& Devi, S. S. (2013). The influence of governance structure and strategic corporate social responsibility toward sustainability reporting quality. Business Strategy and the Environment, 23(4), 217-235. https://doi.org/10.1002/bse.1767

Amran, A., Ooi, S. K., Mydin, R. T., \& Devi, S. S. (2015). The impact of business strategies on online sustainability disclosures. Business Strategy and the Environment, 24(6), 551-564. https://doi.org/10.1002/bse.1837

Amran, A., \& Siti-Nabiha, a. K. (2009). Corporate social reporting in Malaysia: a case of mimicking the West or succumbing to local pressure. Social Responsibility Journal, 5(3), 358-375. https://doi.org/10.1108/17471110910977285

Aras, G., \& Crowther, D. (2008). Governance and sustainability. Management Decision, 46(3), 433448. https://doi.org/10.1108/00251740810863870

Barakat, F. S. Q., López Pérez, M. V., \& Rodríguez Ariza, L. (2014). Corporate social responsibility disclosure (CSRD) determinants of listed companies in Palestine (PXE) and Jordan (ASE). Review of Managerial Science, 9(4), 681-702. https://doi.org/10.1007/s11846-014-0133-9

Barako, D. G., \& Brown, A. M. (2008). Corporate social reporting and board representation: Evidence from the Kenyan banking sector. Journal of Management and Governance, 12(4), 309-324. https://doi.org/10.1007/s10997-008-9053-x

Bear, S., Rahman, N., \& Post, C. (2010). The impact of board diversity and gender composition on corporate social responsibility and firm reputation. Journal of Business Ethics, 97(2), 207-221. https://doi.org/10.1007/s10551-010-0505-2

Boulouta, I. (2013). Hidden Connections: The Link Between Board Gender Diversity and Corporate Social Performance. Journal of Business Ethics, 113(2), 185-197.

https://doi.org/10.1007/s10551-012-1293-7

Boyd, B. (1990). Corporate linkages and organizational environment: A test of the resource dependence model. Strategic Management Journal, 11(6), 419-430. https://doi.org/10.1002/smj.4250110602

Chih, H.-L., Chih, H.-H., \& Chen, T.-Y. (2010). On the determinants of corporate social responsibility: International evidence on the financial industry. Journal of Business Ethics, 93(1), 115-135. 
INTERNATIONAL JOURNAL OF ACADEMIC RESEARCH IN BUSINESS AND SOCIAL SCIENCES

Vol. 9, No. 3, March, 2019, E-ISSN: 222 2-6990 @ 2019 HRMARS

https://doi.org/10.1007/s10551-009-0186-x

Cooke, T. E. (1989). Voluntary Corporate Disclosure by Swedish Companies. Journal of International Financial Management \& Accounting, 1(2), 171-195. https://doi.org/10.1111/j.1467-

646X.1989.tb00009.x

Deegan, C., \& Gordon, B. (1996). A study of the environmental disclosure practices of Australian corporations. Accounting and Business Research, 26(3), 187-199.

https://doi.org/10.1080/00014788.1996.9729510

Fernandez-Feijoo, B., Romera, S., \& Ruiz, S. (2012). Does board gender composition affect corporate social responsibility reporting ? International Journal of Business and Social Science, 3(1), 3139.

Gray, R., Kouhy, R., \& Laver, S. (1995). Corporate social and environmental reporting: a review of the literature and a longitudinal study of UK disclosure. Accounting, Auditing \& Accountability Journalou, 8(2), 47-77. https://doi.org/10.1108/09513571211191833

Guthrie, J., \& Parker, L. D. (1989). Corporate Social Reporting: A Rebuttal of Legitimacy Theory. Accounting and Business Research, 19(76), 343-352.

https://doi.org/10.1080/00014788.1989.9728863

Hackston, D., \& Milne, M. J. (1996). Some determinants of social and environmental disclosures in New Zealand companies. Accounting, Auditing \& Accountability Journal, 9(1), 77-108. https://doi.org/10.1108/09513579610109987

Hafsi, T., \& Turgut, G. (2013). Boardroom diversity and its effect on social performance: Conceptualization and empirical evidence. Journal of Business Ethics, 112(3), 463-479. https://doi.org/10.1007/s10551-012-1272-z

Hambrick, D. C., Cho, T. S., \& Chen, M.-J. (1996). The influence of top management team heterogeneity on firms' competitive moves. Administrative Science Quarterly, 41(4), 659-684. https://doi.org/10.2307/2393871

Hamzah, N., Mohd Saleh, N., \& Mohamed, S. (2015). The Infl uence of Ethnicity on the Reporting of Intellectual Capital. Jurnal Pengurusan, 43(.), 73-87. https://doi.org/10.17576/pengurusan2015-43-07

Haniffa, R., \& Cooke, T. (2002). Culture, corporate governance and disclosure in Malaysian corporations. Abacus, 38(3), 317-349. https://doi.org/10.1017/CB09781107415324.004

Haniffa, R. M., \& Cooke, T. E. (2005). The impact of culture and governance on corporate social reporting. Journal of Accounting and Public Policy, 24(5), 391-430. https://doi.org/10.1016/j.jaccpubpol.2005.06.001

Hillman, A. J., Canella, A. A., \& Harris, I. C. (2002). Women and racial minorities in the boardroom: How do directors differ? Journal of Management, 28(6), 747-763. https://doi.org/10.1016/S0149-2063(02)00192-7

Hillman, A. J., \& Dalziel, T. (2003). Boards of directors and firm performance: Integrating agency and resource dependence perspectives. Academy of Management Review, 28(3), 383-396.

Hooghiemstra, R. (2000). Corporate communication and impression management-new perspectives why companies engage in corporate social reporting. Journal of Business Ethics, 27(1/2), 55-68. https://doi.org/10.1023/A:1006400707757

Hughes, S. B., Anderson, A., \& Golden, S. (2001). Corporate environmental disclosures: Are they useful in determining environmental performance? Journal of Accounting and Public Policy, 
INTERNATIONAL JOURNAL OF ACADEMIC RESEARCH IN BUSINESS AND SOCIAL SCIENCES

Vol. 9, No. 3, March, 2019, E-ISSN: 222 2-6990 @ 2019 HRMARS

20(3), 217-240. https://doi.org/10.1016/S0278-4254(01)00031-X

Janggu, T., Joseph, C., \& Madi, N. (2007). The current state of corporate social responsibility among industrial companies in Malaysia. Social Responsibility Journal, 3(3), 9-18. https://doi.org/10.1108/17471110710835536

Jia, M., \& Zhang, Z. (2012). Women on boards of directors and corporate philanthropic disaster response. China Journal of Accounting Research, 5(1), 83-99. https://doi.org/10.1016/j.cjar.2012.01.001

Kang, H., Cheng, M., \& Gray, S. J. (2007). Corporate governance and board composition: Diversity and independence of Australian boards. Corporate Governance, 15(2), 194-207. https://doi.org/10.1111/j.1467-8683.2007.00554.x

Khan, M. H.-U.-Z. (2010). The effect of corporate governance elements on corporate social responsibility (CSR) reporting: Empirical evidence from private commercial banks of Bangladesh. International Journal of Law and Management, 52(2), 82-109. https://doi.org/10.1108/17542431011029406

KPMG. (2015). Currents of change: The KPMG Survey of Corporate Responsibility Reporting 2015, $1-48$.

KPMG. (2017). The road ahead. Nature Nanotechnology, 8(11), 792-793. https://doi.org/10.1038/nnano.2013.238

MCCG. (2012). Malaysian Code on Corporate Governance 2012. 2012.

MCCG. (2017). Malaysia Code of Corporate Governance, (c), 1-4.

Mohd Ghazali, N. A. (2007). Ownership structure and corporate social responsibility disclosure: some Malaysian evidence. Corporate Governance: The International Journal of Business in Society, 7(3), 251-266. https://doi.org/10.1108/14720700710756535

Mohd Ghazali, N. A. (2010). Ownership structure, corporate governance and corporate performance in Malaysia. International Journal of Commerce and Management, 20(2), 109119. https://doi.org/10.1108/10569211011057245

Oba, V. C., \& Fodio, M. I. (2012). Board characteristics and the quality of environmental reporting in Nigeria . corporate governance in Nigeria. Journal of Accounting and Management, 2(2), 3348.

Olieveira, Jonas; Lima Rodrigues, Lima; Craig, R. (2011). Risk-related disclosures by non-finance companies: Portuguese practices and disclosure characteristics Jonas. Managerial Auditing Journal, 26(9), 817-839. https://doi.org/http://dx.doi.org/10.1108/MRR-09-2015-0216

Pfeffer_Salancik_1978_Kapitel7.(n.d.).

Pfeffer, J., \& Salancik, G. (1978). Chapter 3. Social Control of Organizations. The External Control of Organizations: A Resource Dependence Perspective, 39-52. https://doi.org/10.2307/2392573

Post, C., Rahman, N., \& Rubow, E. (2011). Green Governance: Boards of Directors' Composition and Environmental Corporate Social Responsibility. Business \& Society (Vol. 50). https://doi.org/10.1177/0007650310394642

Prado-Lorenzo, J.-M., Gallego-Alvarez, I., \& Garcia-Sanchez, I. M. (2009). Stakeholder engagement and corporate social responsibility reporting: the ownership structure effect. Corporate Social Responsibility and Environmental Management, 16(2), 94-107. https://doi.org/10.1002/csr.189

Rao, K. K., Tilt, C. A., \& Lester, L. H. (2012). Corporate governance and environmental reporting: an 
INTERNATIONAL JOURNAL OF ACADEMIC RESEARCH IN BUSINESS AND SOCIAL SCIENCES

Vol. 9, No. 3, March, 2019, E-ISSN: 222 2-6990 @ 2019 HRMARS

Australian study. Corporate Governance: The International Journal of Business in Society, 12(2), 143-163. https://doi.org/10.1108/14720701211214052

Rao, K., \& Tilt, C. (2015). Board composition and corporate social responsibility: The role of diversity, gender, strategy and decision making. Journal of Business Ethics, 1-21. https://doi.org/10.1007/s10551-015-2613-5

Rao, K., \& Tilt, C. (2016). Board diversity and CSR reporting: an Australian study. Meditari Accountancy Research, 24(2). https://doi.org/http://dx.doi.org/10.1108/MRR-09-2015-0216

Rose, C. (2007). Does female board representation influence firm performance? The Danish evidence. Corporate Governance: An International Review, 15(2), 404-413. https://doi.org/10.1111/j.1467-8683.2007.00570.x

Said, R., Hj Zainuddin, Y., \& Haron, H. (2009). The relationship between corporate social responsibility disclosure and corporate governance characteristics in Malaysian public listed companies. Social Responsibility Journal, 5(2), 212-226. https://doi.org/10.1108/17471110910964496

Saleh, M., Zulkifli, N., \& Muhamad, R. (2010). Corporate social responsibility disclosure and its relation on institutional ownership. Managerial Auditing Journal, 25(6), 591-613. https://doi.org/10.1108/02686901011054881

Smith, M., Yahya, K., \& Amiruddin, A. M. (2007). Environmental Disclosure and Performance Reporting in Malaysia. Asian Review of Accounting, 15(2), 185-199. https://doi.org/10.1108/13217340710823387

Sutantoputra, A. W. (2009). Social disclosure rating system for assessing firms' CSR reports. Corporate Communications: An International Journal, 14(1), 34-48. https://doi.org/10.1108/13563280910931063

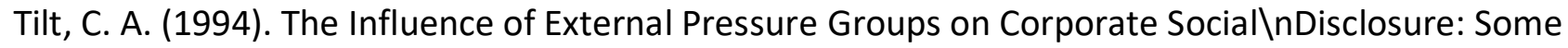
Empirical Evidence. Accounting, Auditing \& Accountability Journal, 7(4), 47-72. https://doi.org/10.1108/09513579410069849

UNDP, IFC, \& IPIECA. (2018). Mapping the Oil and Gas industry to the Sustainable Development Goals : An Atlas.

van Knippenberg, D., De Dreu, C. K. W., \& Homan, A. C. (2005). Work Group Diversity and Group Performance : An Integrative Model and Research Agenda Work Group Diversity and Group Performance : An Integrative Model and Research Agenda. Journal of Applied Psychology, 89(6), 1008-1022. https://doi.org/10.1037/0021-9010.89.6.1008

Watson, W. E., Johnson, L., \& Merritt, D. (1998). Team Orientation, Self-Orientation, and Diversity in Task Groups: Their Connection to Team Performance Over Time. Group \& Organization Management, 23(2), 161-188. https://doi.org/10.1177/1059601198232005

Westphal, J. D., \& Milton, L. P. (2000). How experience and network ties affect the influence of demographic minorities on corporate boards. Administrative Science Quarterly, 45(2), 366398. https://doi.org/10.2307/2667075

Zahra, S. A., \& Pearce II, J. A. (1989). Boards of directors and corporate financial performance: A review and integrative model. Journal of Management, 15(2), 291-334. https://doi.org/10.1177/014920638901500208

Zainal, D., Zulkifli, N., \& Saleh, Z. (2013a). A longitudinal analysis of corporate social responsibility reporting (CSRR) in Malaysia public listed firms: Pre-and post-mandatory CSRR requirement. 
International Journal of Advanced Research in Management and Social Sciences, 2(1), 245-262. Retrieved from http://garph.co.uk/IJARMSS/Jan2013/18.pdf

Zainal, D., Zulkifli, N., \& Saleh, Z. (2013b). Corporate board diversity in Malaysia: longitudinal analysis of gender and nationality diversity. International Journal of Academic Research in Accounting, Finance and Management Sciences, 3(1), 136-148.

Zeghal, D., \& Ahmed, S. A. (1990). Comparison of social responsibility information disclosure media used by Canadian firms. Accounting, Auditing \& Accountability Journal, 3(1), 38-53. https://doi.org/http://dx.doi.org/10.1108/MRR-09-2015-0216

Zhang, L. (2012). Board demographic diversity, independence, and corporate social performance. Corporate Governance: The International Journal of Business in Society, 12(5), 686-700. https://doi.org/10.1108/14720701211275604 